\title{
IDENTITY AND AN IDENTITY CRISIS: THE IDENTITY CRISIS OF FIRST-YEAR FEMALE STUDENTS AT LATVIAN UNIVERSITIES AND THEIR SOCIODEMOGRAPHIC INDICATORS
}

\author{
Aivis Dombrovskis \\ University of Daugavpils, Latvia
}

\begin{abstract}
This paper reflects the results of a study that was aimed at finding links between identity crises and the sociodemographic indicators of first-year female students at Latvian universities. The research cohort consists of $501(N=501)$ students aged 18 to 27 $(M=20.33$; $S D=1.937)$. The author used the Identity Distress Survey (IDS) for the research (Berman et al., 2004), as well as the sociodemographic data of the students. The Spearman correlation coefficient was used to analyse links between IDS indicators, and detailed analysis of links between IDS factors was also conducted.
\end{abstract}

Keywords: Identity crisis; female; female students; identity; Identity Distress Survey; IDS; IKA; Latvia; students; social environment; sociodemographic indicators.

\section{Introduction}

Scholars are still debating the issue of whether there is a unified concept about identity, and they are trying to define the content thereof. Still, while people are looking for a single definition of identity, it is clear that an integral part of the emergence of an identity is an identity crisis. It is universally known that identities emerge under the influence of the surrounding environment, and so this paper depicts research results about links that have been discovered when examining the sociodemographic indicators and identity crisis indicators of firstyear female students at Latvian universities. There were 501 respondents aged 18 to 27 . The data were obtained by using Microsoft Excel, Word, and the SPSS-19 data processing programme. The data were analysed by the use of descriptive statistics, and links were analysed on the basis of a non-parametric statistical method - the Spearman correlation coefficient. The author has examined the concept and content of identity and the concept and content of identity crisis, and he has also offered detailed analysis of the sociodemographic data of the research cohort. The Identity Distress Survey (Berman et al., 2004) is described in detail, with a presentation and analysis of the research data, conclusions about the results, and a statement of limitations that relate to the research project. 


\section{The Paper}

Among the first to define the name and content of the concept of identity was Erikson, who mostly defined identity as a subconscious process that merges a personality into a single whole and forms links between the individual and the social world (Eriksons, 1998).

Erikson argues that identity can be described with the answer to the question "who am I?" He also indicates that identities are not always positive in that sometimes individuals choose a negative identity to maintain their sense of integrity. An example would be identifying oneself with a violent person and then becoming a violent person, too (Eriksons, 1998).

One of the more successful correlations of views about identity today is that of Sedikides and Brewer (Sedikides \& Brewer, 2001), who argue that approaches that seek to explain identity tend to focus on one of three levels of definitions - the individual level, the relationship level and the collective level.

The individual level, or personal identity, applies to aspects of defining oneself, and that includes goals, values and faith (Marcia, 1966; Waterman, 1999), religious and spiritual aspects (MacDonald, 2000), behavioural standards and decision-making (Atkins et al., 2005; Hardy \& Carlo, 2005), self-respect and self-confidence (Kernis et al., 2008; Sedikides \& Gregg, 2008), desires, fears and the views that one has about one's life in future (Markus \& Nurius, 1986), as well as the history of one's life (McAdams, 2006). Scholars who have focused on the individual level of identity particularly emphasise individual processes, emphasising the importance of the roles that are represented by individuals in the study and development of their identities (Cote \& Levine, 2002).

The level of relationships also points to the individual's role in relation to other people, including parts of individual identity such as being a child, a spouse, a parent, a colleague, etc. The identity of relationships applies not just to roles that the individual has taken on, but also to the way in which the individual who has accepted them defines and interprets them (Vingoles et al., 2011). Several authors have argued that identity can also be defined from an intrapersonal perspective (Bamberg, 2004; Chen et al., 2006; Kerpelman et al., 1997), in the context of a family environment (Grotevant et al., 2000; Manzi et al., 2006), or in line with roles that individuals have accepted and "perform" in larger social systems (Thatcher \& Zhu, 2006). Markova and Swann argue that if the new identity of the individual's relationships is to be stable and secure, it must be identified, accepted and recognised in the relevant social target audience (Markova, 1987; Swann, 2005).

The level of collective identity is applied to the extent to which people identify themselves to a group and social categories to which the groups belong. 
Individuals assign importance to groups and categories in accordance with how they feel when identifying with these groups or their ideologies and attitudes (Ashmore et al., 2004; De Fina, 2007; Tajfel \& Turner, 1986; Van Zomeren et al., 2008). Collective identity can also be explained as a sense of belonging to a social group or category that can include belonging to a race or an ethnic group (Taylor, 1997; Cross, 1971; Helms, 1993; Phinney, 1990), to nationality (Schildkraut, 2005, 2007), to a religion (Cohen et al., 2005), to a gender group (Bussey \& Bandura, 1999; Jones, 1997; Josselson, 1987), to sexual orientation (Cass, 1979; D'Augelli, 1994), or to feminism (Downing \& Roush, 1985). It can also be a small group such as a family or the team at work (Haslam \& Naomi, 2011; Scabini \& Manzi, 2011). People perceive and define their identities not just through social units, but also with material artefacts (Belk, 1988; Mittal, 2006), which indicates that people also have a material identity (Vingoles et al., 2011).

Waterman argues that identities emerge during identity crisis, when there is a re-evaluation of various life goals, values and beliefs, as well as a search for alternatives in terms of new life goals, with life being given a new purpose (Waterman, 1985). This is a process that is affected by external social circumstances, but the effects on each person is individual (Raskin, 2002).

Erikson (Eriksons, 1998) was the one to introduce the concept of an identity crisis, arguing that the insecurity and worries that teenagers experience when they become youths create a lack of knowledge and confusion about the present and the future in terms of the roles that they will have in future. Robbins and Wilner (2001), for their part, describe the identity crisis that college students experience when they have to start a new life after their studies. In the field of social psychology (Shaffer, 2009), identity crises are described as insecurity or even fear about what young people feel when they change and are no longer children. This creates a lack of knowledge and confusion about future life roles that they will have to accept and perform in their lives.

An identity crisis is an integral part of the formation of an identity (Eriksons, 1998; Adams, 2007). During transitional periods, young people pose questions about their future and seek answers to the question of what career to choose, what religious, moral and political values and views they should accept, whether or not they should get married and have children, when to have children and how many children to have, and which social group to join (Shaffer, 2009).

Erikson, Whitbourne and Breakwell argue that humans develop their identities throughout their lives and that this is a dynamic, not a static process (Eriksons, 1998; Whitbourne, 1986; Breakwell, 2010). Researchers also say that identity crises are found among middle-aged people (Levinson et al., 1978; Heckausen, 2001). 
Hernandez and his colleagues have studied identity crisis indicators on the basis of the Identity Distress Survey (IDS) (Berman et al., 2004). The researchers studied various social groups (in terms of gender, race and ethnicity) and immigrant groups to find out that statistically major differences were determined not by race, ethnicity or immigrant status, but instead by gender.

Identity crises can also emerge when people face a conflict with their own self-presentation, having to decide immediately what kind of self-image to present if two groups of people encounter each other simultaneously - those for whom two different self-images are presented under different circumstances (Terry et al., 2007).

A sub-scale in the IDS is called "Identity Disorders" (American Psychiatric Association, 1987), and the researchers used it to find out that $23 \%$ of surveyed women had identity disorders, while no men had such disorders. Another subscale, "Identity Problems" (American Psychiatric Association, 1994), showed that $35 \%$ of women and $7.5 \%$ of men in the cohort had identity problems. The researchers found that women also have statistically important results in terms of the identity disorder that relates to anti-social behaviour and headstrong behaviours (Hernandez et al., 2006).

\section{The Cohort}

This study analysed data from $501(\mathrm{~N}=501)$ women aged 18-27 ( $\mathrm{M}=20.33$; $\mathrm{SD}=19.37)$. $44.7 \%$ of the respondents were between $19(\mathrm{~N}=199)$ and 20 $(\mathrm{N}=117)$ years old, which corresponds to the fact that they were first-year students after finishing high school at the age of 18 or $19.38 .3 \%$ of respondents lived with their parents, $28.9 \%$ in their own home, and $32.7 \%$ in university dormitories. $47.7 \%$ of respondents grew up in cities, while $52.3 \%$ grew up in the countryside. $73.5 \%$ were unmarried, $6.8 \%$ were married, $18.6 \%$ were cohabiting with someone, and $1.2 \%$ were divorcees.

In terms of children, $89.8 \%$ of respondents had none, while $10.2 \%$ had one or more child. $96.8 \%$ of respondents were attending their first university, while $3.2 \%$ were attending a second one. Respondents were studying at the University of Latvia (29.1\%), the University of Daugavpils (20.2 \%), the University of Liepāja (20.2\%), the Cēsis branch of the Rìga Academy of Pedagogy and Educational Administration (19.6\%), and the Latvian Agricultural University (3.8\%), which meant that the respondents came from all of Latvia's regions - Rīga, Latgale, Kurzeme, Vidzeme and Zemgale. $84 \%$ of the respondents were Latvians, followed by Russians (11.4\%), Polish (1.6\%) Belarusians (1.4\%), Lithuanians (0.6\%), and one Gipsy woman $(0.2 \%)$ and one Tatar woman $(0.2 \%)$. 


\section{The Instruments}

\section{Adaptation of the instrument}

Adaptation of the IDS first involved the calculation of the harmonisation of the scale. The scale related to the first seven questions was $\alpha=.74$, while the whole scale (10 questions) was $\alpha=.76$. Berman et al., (2004) argued that the internal harmony of calculations was $\alpha=.84$. The Cronbach Alpha test showed a sufficiently high level of internal harmony was <.7 (Raščevska, 2005).

The IDS test-retest measurements were good, because in all items it was $\mathrm{R}_{\mathrm{s}}=1 ; \mathrm{p}<.01$.

IDS surveys satisfy the most important psychometric demands for test adaptation. It can be said that this has been adapted in the Latvian environment and can be used in future for research and practical work (Dombrovskis, 2014a; 2014b).

\section{The research instrument}

The Identity Distress Survey, or IDS (Berman et al., 2004) determines the level of an identity crisis, as related to unresolved or unfulfilled identity issues. The research is based on the DSM-III-R (APA, 1987) identity crisis criteria, but it can also be used to evaluate DSM-IV (APA, 1994) identity problem criteria, because as the designers of the survey have pointed out, identity problems cannot always be seen as an identity crisis.

The IDS helps to determine how young people survive serious complications in the development of their identities, also making it possible to study links between identity problems and other aspects of psychological functions (Berman et al., 2004). It was chosen in this study to find an answer to the research question about links between an identity crisis and the sociodemographic indicators of female university students.

Respondents were asked to answer ten questions in the survey, offering an answer to the first nine questions on the basis of the Likert scale, with 1 meaning not at all, 2 meaning not much, 3 meaning average level, 4 meaning strong, and 5 meaning very strong. This related to how often respondents were recently embittered, fearful or concerned about identity issues such as long-term goals, career choices, friendship, sexual orientation and behaviour, religion, values or viewpoints, as well as loyalty to a group. The tenth question involved a special evaluation scale with a time interval by months (Hernandez et al., 2006). This related to how long the respondent has felt doubts about these issues and how much the symptoms hinder everyday activities. The internal harmonisation of the original survey version was $\alpha=.84$, while at the retest level it was $\alpha=.82$. The original survey shows convergent validity with other measurements of the development of identities (Berman et al., 2004). 


\section{Results}

\section{Analysis of overall connections}

Researchers found that overall identity crisis indicators have very close statistical connections with the age of the respondents (Age of respondents) and the issue of whether the respondents have brothers or sisters (Existence of brothers or sisters) (Table 1).

Medium-level connections were found in relation to whether the respondents were married (Family status - married/unmarried) and whether they had children (Children - children or no children). The same was true in terms of how many universities they had attended (University studies - first or second university) (Table 1).

Analysis of the overall IDS identity crisis indicators and the sociodemographic indicators related to the marriage of parents (The parental marriage model after marriage repeatability), to the respondent's nationality (Respondent's nationality) and the nationality of the respondent's parents (Respondent's father's nationality; Respondent's mother's nationality) did not demonstrate any connections (Table 1).

Table 1 Identity Crisis Survey connections between identity crises and sociodemographic indicators

\begin{tabular}{|l|c|c|c|c|c|c|c|c|c|}
\hline $\begin{array}{c}\text { IDS } \\
\text { indica- } \\
\text { tors }\end{array}$ & Age & $\begin{array}{c}\text { Family } \\
\text { status }\end{array}$ & $\begin{array}{c}\text { Chil- } \\
\text { dren }\end{array}$ & $\begin{array}{c}\text { Paren- } \\
\text { tal } \\
\text { marria } \\
\text { ge }\end{array}$ & Siblings & $\begin{array}{c}\mathbf{1}^{\text {st }} \text { or 2 } \\
\text { universi- } \\
\text { ty }\end{array}$ & $\begin{array}{c}\text { Respon- } \\
\text { dent's } \\
\text { Nationa- } \\
\text { lity }\end{array}$ & $\begin{array}{c}\text { Father's } \\
\text { nationa- } \\
\text { lity }\end{array}$ & $\begin{array}{c}\text { Mother's } \\
\text { nationa- } \\
\text { lity }\end{array}$ \\
\hline $\begin{array}{l}\text { Spearman } \\
\text { correla- } \\
\text { tion }\end{array}$ &.$- .128 *$ &.$- .107 *$ &.- .088 & -.023 & $\mathbf{- . 1 3 3 * *}$ & $\mathbf{- . 1 1 4 \%}$ & .007 & -.021 & -.019 \\
\hline $\begin{array}{l}\text { Bilateral } \\
\text { signify- } \\
\text { cance }\end{array}$ & .004 & .017 & .049 & .605 & .003 & .010 & .867 & .647 & .664 \\
\hline
\end{tabular}

Data from A. Dombrovskis in this study

More detailed analysis of the connections was conducted in relation to connections between identity crisis measurement sub-indicators and sociodemographic indicators among the respondents.

Detailed analysis of connections

The category Age group showed correlations with Career choice $\left(\mathrm{R}_{\mathrm{s}}=-.162\right.$; $\mathrm{p}=.00)$, Friendship $\left(\mathrm{R}_{\mathrm{s}}=-.090 ; \mathrm{p}=.044\right)$, Group loyalty $\left(\mathrm{R}_{\mathrm{s}}=-.116 ; \mathrm{p}=.009\right)$, and DxIV (specification of identity problems) $\left(\mathrm{R}_{\mathrm{s}}=-.132 ; \mathrm{p}=.132\right)$. 
Family status correlated with Long-term goals $\left(\mathrm{R}_{\mathrm{s}}=.115 ; \mathrm{p}=.010\right)$, Friendship $\left(\mathrm{R}_{\mathrm{s}}=-.121 ; \mathrm{p}=.007\right)$, and DxIV (specification of identity problems) $\left(\mathrm{R}_{\mathrm{s}}=-.094 ; \mathrm{p}=.036\right)$.

The issue of whether the respondents had children showed that Have children had correlations with Career choice $\left(\mathrm{R}_{\mathrm{s}}=.093 ; \mathrm{p}=.038\right)$ and Friendship $\left(\mathrm{R}_{\mathrm{s}}=.094 ; \mathrm{p}=.036\right)$, while Have no children had negative correlations with Career choice $\left(\mathrm{R}_{\mathrm{s}}=-.093 ; \mathrm{p}=.038\right)$ and Friendship $\left(\mathrm{R}_{\mathrm{s}}=-.94 ; \mathrm{p}=.036\right)$

Married parents, $2^{\text {nd }}$ marriage for mother, $1^{\text {st }}$ marriage for father had correlations with Long-term goals $\left(\mathrm{R}_{\mathrm{s}}=-.090 ; \mathrm{p}=.044\right)$, and DxIV (specification of identity problems) $\left(\mathrm{R}_{\mathrm{s}}=-.090 ; \mathrm{p}=.044\right)$, and DxIV (specification of identity problems $)\left(\mathrm{R}_{\mathrm{s}}=-.102 ; \mathrm{p}=.023\right)$.

The indicator related to having siblings or being the only child in the family also had correlations. Younger sister had correlations with Career choice $\left(\mathrm{R}_{\mathrm{s}}=-\right.$ $.150 ; \mathrm{p}=.001)$, Sexuality $\left(\mathrm{R}_{\mathrm{s}}=-.146 ; \mathrm{p}=.001\right)$, Values $\left(\mathrm{R}_{\mathrm{s}}=-.152 ; \mathrm{p}=.001\right)$, and Group loyalty $\left(\mathrm{R}_{\mathrm{s}}=-.118 ; \mathrm{p}=.008\right)$. Only child had correlations with Career choice $\left(\mathrm{R}_{\mathrm{s}}=.109 ; \mathrm{p}=.014\right)$, Sexuality $\left(\mathrm{R}_{\mathrm{s}}=.088 ; \mathrm{p}=.048\right)$, Group loyalty $\left(\mathrm{R}_{\mathrm{s}}=.090\right.$; $\mathrm{p}=.044)$, and DxIV (specification of identity problems) $\left(\mathrm{R}_{\mathrm{s}}=.095 ; \mathrm{p}=.033\right)$.

Another indicator related to how many universities the respondents had attended, with many of them having attended more than one university. First university had statistically important correlations with Career choice $\left(\mathrm{R}_{\mathrm{s}}=.151\right.$; $\mathrm{p}=.001)$, Friendship $\left(\mathrm{R}_{\mathrm{s}}=.098 ; \mathrm{p}=.029\right)$, and DxIV (specification of identity problems $)\left(\mathrm{R}_{\mathrm{s}}=.107 ; \mathrm{p}=.017\right)$. Second university had correlations with Career choice $\left(\mathrm{R}_{\mathrm{s}}=-.151 ; \mathrm{p}=.001\right)$, Friendship $\left(\mathrm{R}_{\mathrm{s}}=-.98 ; \mathrm{p}=.029\right)$, and DxIV (specification of identity problems) $\left(\mathrm{R}_{\mathrm{s}}=-.107 ; \mathrm{p}=.017\right)$.

When it came to the nationality of respondents, Latvian had correlations with Friendship $\left(\mathrm{R}_{\mathrm{s}}=.090 ; \mathrm{p}=.014\right)$ and Sexuality $\left(\mathrm{R}_{\mathrm{s}}=-.117 ; \mathrm{p}=.009\right)$, while Russian had correlations with Sexuality $\left(\mathrm{R}_{\mathrm{s}}=.099 ; \mathrm{p}=.027\right)$.

Father's nationality had correlations with Friendship $\left(\mathrm{R}_{\mathrm{s}}=-.113 ; \mathrm{p}=.011\right)$ and Sexuality $\left(\mathrm{R}_{\mathrm{s}}=.132 ; \mathrm{p}=.003\right)$, while Mother's nationality had correlations with Sexuality $\left(\mathrm{R}_{\mathrm{s}}=.018 ; \mathrm{p}=.015\right)$.

\section{Discussion}

Elements of an identity crisis among the young women could be seen in factors such as age, university studies, long-term goals, career choices, friendship, children, belonging to a social group, and sexuality. This is line with the argument by Arnett, Rossi and Mebert, and Shaffer that the period of life after completing high school is particularly important, because the lives of young people aged 18 to 25 are full of major changes. They must study their new future opportunities when it comes to relationships, work, political orientations and life goals (Arnett, 2000). They must launch their professional 
careers (Rossi \& Mebert, 2011). Shaffer (Shaffer, 2009) agrees, pointing out that female college students are more concerned about their professional identity than schoolchildren are, adding that they are concerned about aspects of identity such as sexuality and relationships, because the issue of striking a balance between work and family goals is important.

This study shows that the identity crisis is not all-encompassing and that it can be linked to a component of identity that is in line with the statements by Shaffer and Marcia that only $5 \%$ of survey respondents deal with identity issues such as professional choices, attitudes about gender roles, religion and political ideology, with equal identity statuses in accordance with the classification of status that was created by Marcia (Marcia, 1980). For the remaining $95 \%$, these categories are "scattered" among various statuses (Shaffer, 2009), with some of the categories having the status of an identity crisis.

\section{Conclusions}

1. Identity crisis indicators of first- year female students are related to their age, marital status, whether they sibilings, and their university studies.

2. First-year female university students have identity crisis indicators that decline as they grow older, get married, have children and determine what they want to study.

3. Overall identity crisis indicators for first-year female students have much to do with the family environment in which they grew up and with whether or not they have brothers and sisters.

4. The identity crisis for first-year female students in terms of career choice and future long-term goals has to do with indicators such as their age, marriage status and whether or not they have children, as well as with the marriage of their parents, whether they have siblings, and their university studies.

5. The identity crisis of first-year female students in terms of friendship has to do with their age, their marriage status, whether they have children, their university studies, and their nationality and that of their fathers.

6. The identity crisis of first-year female students in terms of sexuality, sexual orientation and sexual orientation relates to whether they have siblings, themselves, and the nationality of their parents.

7. The identity crisis of first-year female students in terms of group loyalty and the desire to belong to a social group and a set of student values is linked to whether they have siblings, while none of the respondents spoke of an identity crisis that relates to religious belonging. 
8. The identity crisis of first-year female students in terms of long-lasting identity problems has to do with sociodemographic indicators such as their age, their marriage status, whether they have siblings, and their university studies.

\section{Limitations}

This study did not research men and their identity crisis indicators, as related to sociodemographic indicators. More extensive research should be done with a wider range of ages among respondents.

\section{References}

Adams, G. R. (2007). Identity status. Encyclopedia of Social Psychology. SAGE Publications. Arnett, J. J. (2000). Emerging adulthood: A theory of development from the late teens through the twenties. American Psychologist, 55, 469-480.

American Psychiatric Association. (1987). Diagnostic and statistical manual of mental disorders (3rd ed. rev.). Washington.

American Psychiatric Association. (1994). Diagnostic and statistical manual of mental disorders (4rd ed. rev.).Washington.

Ashmore, R. D., Deaux, K., \& McLaughlin-Volpe, T. (2004). An organizing framework for collective identity: Articulation and significance of multidimensionality. Psychological Bulletin, 130, 80-114.

Atkins, R., Hart, D., \& Donnelly, T. M. (2005). The Association of Childhood Personality type with volunteering during adolescence. Merrill-Palmer Quarterly, 51, 145-162.

Bamberg, M. (2004). Talk, small stories, and adolescent identities. Human Development, 47, $366-369$.

Belk, R. W. (1988). Possessions and the extended self. Journal of Consumer Research, 15, 139-168.

Berman, S. L., Montogomery, M. J., \& Kurtines, W. M. (2004). The development and validation of a measure of identity distress. Identity: An International Journal of Theory and Research, 4, 1-8.

Breakwell, G. M. (2010). Resising representations and identity processes. Online Journal. Papers on Social Representations, 19 (6.1-6.11).

Bussey, K., \& Bandura, A. (1999). Social cognitive theory of gender development and differentiation. Psychological Review, 106, 676-713.

Cass, V. C. (1979). Homosexual identity formation: A theoretical model. Journal of homosexuality, 4, 219-235.

Chen, S., Boucher, H. C., \& Tapias, M. P. (2006). The relational self revealed: Integrative conceptualization of the implications and interpersonal life. Psychological Bulletin, 132, 151-179.

Cohen, A. B., Hall, D. E., Koenig, H. G., \& Meador, K. G. (2005). Social versus individual motivation: Implications for normative definitions of religions orientation. Personality and Social Psychology Review, 9, 48-61.

Cote, J. E., \& Levine, C. G. (2002). Identity formation, agency, and culture: A social psychological synthesis. Mahwah, NJ: Lawrence Erlbaum Associates. 
Aivis Dombrovskis. Identity and an Identity Crisis: the Identity Crisis of First-Year Female Students at Latvian Universities and their Sociodemographic Indicators

Cross, W. E. (1971). The negro to black conversion expierence. Toward a psychology of black liberation. Black World, 20 (9), 13-27.

D'Augelli, A. R. (1994). Identiy development and sexual orientation: Toward a model of lesbian, gay, and bisexual development. In E. J. Trickett, R. J. Watts, \& D. Birman (Eds.), Human diversity: Perspectives on people in context (pp. 312 - 333). San Francisco: Jossey-Bass.

De Fina, A. (2007). Code-switching and the construction of ethnic identity in a community of practice. Language in Society, 36, 371-392.

Dombrovskis, A. (2014a). Latvijas sieviešu feministiskās identitātes dimensijas prognozējošie faktori. Daugavpils Universitāte., Nepublicēta disertācija.

Dombrovskis, A. (2014b). Identitātes krīzes aptaujas psihometriskie rādītāji Latvijas vidē. Sociālo Zinātņu Vēstnesis. DU Sociālo Zinātņu Fakultāte. Sociālo Pētījumu Institūts., Daugavpils Universitāte. 1 - (18), pp. 60 -81.

Downing, N. E., \& Roush, K. L. (1985). From passive acceptance to active commitment: A model of feminist identity development for women. The Counseling Psychologist, 13, 695-709.

Eriksons, E. H. (1998). Identitāte: Jaunība un krīze. Jumava.

Grotevant, H. D., Dunbar, N., Kohler, J. K., \& Esau, A. M. L. (2000). Adoptive identity: How contexts within and beyond the family shape developmental pathways. Family Relations, 49, 379-387.

Haslam, S. A., \& Naomi, E. (2011). Identity processes in organizations. In S. J. Schwartz et al. (Eds.), Handbook of identity theory and research. Springer Science+Business Media.

Hardy, S. A., \& Carlo, G. (2005). Identity as a source of moral motivation. Human Development, 48, 232-256.

Heckhausen, J. (2001). Adaptation and resilience in midlife. In M. E. Lachman (Ed.), Handbook of midlife development (pp. 345-394). New York: Wiley.

Helms, J. E. (Ed.) (1993). Black and white racial identity: Theory, research, and practice. Westport, CT: Praeger.

Hernandez, L., Montgomery, M. J., \& Kurtines, W. M. (2006). Identity distress and adjustment problems in at-risk adolescents. Identity: An International Journal of Theory and Research, 6, 27-33.

Jones, S. R. (1997). Voices of identity and difference: A qualitative exploration of the multiple dimensions of identity development in women college students. Journal of College Student Development, 38, 376-386.

Josselson, R. (1987). Finding herself: Pathways to identity development in women. San Francisko: Jossey-Bass.

Kernis, M. H., Lakey, C. E., \& Heppner, W. L. (2008). Secure versus fragile self-esteem as a predictor of verbal defensiveness: Converging findings across three different markers. Journal of Personality, 76, 477-512.

Kerpelman, J. L., Pittman, J. F., \& Lamke, L. K. (1997). Toward a microprocess perspective on adolescent identity development: An identity control theory approach. Journal of Adolescent Research, 12, 325-346.

Levinson, D. J., Darrow, C., Klein, E. B., Levinson, M. H., \& McKee, B. (1978). The seasons of a man's life. New York, NY: Alfred A. Knopf.

MacDonald, D. A. (2000). Spirituality: Description, measurement, and relation to the five factor model of personality. Journal of Personality, 68, 153-197

Marcia, J. E. (1980). Identity in adolescence. In J. Adelson (Ed.), Handbook of adolescent psychology (pp. 159-188). New York: John Wiley. 
Marcia, J. E. (1966). Development and validation of Ego-identity status. Journal of Personality and Social Psychology, 3, 551-559.

Markova, I. (1987). Knowledge of the self through interaction. In K. Yardley \& T. Honess (Eds.), Self and identity: Psychosocial perspectives (pp. 65-80). New York: Wiley.

Markus, H., \& Nurius, P. (1986). Possible selves. American Psychologist, 41, 954-969.

Manzi, C., Vignoles, V. L., Regalia, C., \& Scabini, E. (2006). Cohesion and enmeshment revisited: Differentiation, identity, and well-being in two European cultures. Journal of Marriage and Family, 68, 673-689.

McAdams, D. P. (2006). The problem of narrative coherence. Journal of Constructivist Psychology, 19, 109-125.

Mittal, B. (2006). I, me, and mine - how products become consumers' extended selves. Journal of Consumer Research, 5, 550-562.

Phinney, J. S. (2000). Identity formation among U.S. ethnic adolescents from collectivist cultures. Paper presented at the Biennial meeting of the Society for Research on Adolescents. Chicago.

Raščevska, M. (2005). Psihologisko testu un aptauju konstruēšana un adaptācija. Rīga: Raka.

Raskin, P. (2002). Identity in adulthood: Reflections on recent theory and research. Identity: An International Journal of Theory and Research, 2 (1), 101-108.

Robbins, A., \& Wilner, A. (2001). Quarterlife crisis: The unique challenges of life in your twenties. NY: Penguin Putnam. New York.

Rossi, N. E., \& Mebert, C. J. (2011). Does a quarterlife crisis exist? The Journal of Genetic Psychology, 172 (2), 141-161.

Scabini, E., \& Manzi, C. (2011). Family processes and idnetity. In S. J. Schwartz et al. (Eds.), Handbook of identity theory and research. Springer Science+ Business Media.

Sedikides, C., \& Brewer, M. B. (2001). Individual self, relational self, collective self. Philadelphia, Psychology Press.

Sedikides, C., \& Gregg, A. P. (2008). Self-enhancement: Food for thought. Perspectives on Psychological Science, 3, 102-116.

Shaffer, D. R. (2009). Idenity crisis. Encyclopedia of Social Psychology. SAGE Publications.

Schildkraut, D. J. (2007). Defining american identity in the twenty-first century: How much "there" is there? The Journal of Politics, 69, 597-615.

Schildkraut, D. J. (2005). Press “one” for english: Language policy, public opinion, and American identity. Princeton, NJ: Princeton University Press.

Swann, W. B., \& Jr. (2005). The self and identity negotiation. Interaction Studies, 6, 69-83.

Tajfel, H., \& Turner, J. C. (1986). The social identity theory of intergroup behavior. In S. Worchel \& W. G. Austin (Eds.), The psychology of intergroup behavior (pp. 7-24). Chicago. Nelson Hall.

Taylor, D. M. (1997). The quest for collective identity: The plight of disadvantaged ethnic minorities. Canadian Psychology, 38 (3), 174-190.

Terry, M., Sweeny, K., \& Shepperd, J. (2007). Self-presentation. Encyclopedia of Social Psychology. SAGE Publications.

Thatcher, S. M. B., \& Zhu, X. (2006). Changing identities in a changing workplace: Identification, identity enactment, self-verification, and telecommuting. Academy of Management Review, 31, 1076-1088.

Van Zomeren, M., Postmes, T., \& Spears, R. (2008). Toward an integrative social identity model of collective action: A quantitative research synthesis of three sociopsychological perspectives. Psychological Bulletin, 134, 504-535. 
Aivis Dombrovskis. Identity and an Identity Crisis: the Identity Crisis of First-Year Female Students at Latvian Universities and their Sociodemographic Indicators

Vignoles, V. L., Schwartz, S. J., \& Luyckx, K. (2011). Introduction: Toward an integrative view of identity. In S. J.Schwartz et al. (Eds.), Handbook of identity theory and research. Springer Science+Business Media, LLC 2011.

Waterman, A. S. (1999). Identity, the identity statuses, and identity status development: A contemporary statement. Developmental Review, 19, 591-621.

Waterman, A. S. (1985). Identity in the context of adolescent psychology. In A. S. Waterman (Ed.), Identity in adolescence: Progress and contents: (New directions for child development, No. 30). San Francisco: Jossey-Bass.

Whitbourne, S. K. (1986). The me I know: A study of adult identity. New York: SpringerVerlag. 